\title{
DESAIN PERANGKAT PEMBELAJARAN FISIKA DENGAN METODE REAL EXPERIMENTS DAN VIRTUAL EXPERIMENTS
}

\author{
Hikmawati $^{1)}$, Kosim $^{1)}$, Sutrio ${ }^{1)}$ \\ 1)Program Studi Pendidikan Fisika, FPMIPA, Universitas Mataram, Mataram, NTB, Indonesia \\ Corresponding author: Hikmawati \\ E-mail : hikmawati@unram.ac.id
}

Diterima 19 November 2019, Disetujui 27 November 2019

\begin{abstract}
ABSTRAK
Penelitian ini bertujuan untuk mengembangkan perangkat pembelajaran fisika dengan metode real experiments dan virtual experiments sebagai upaya meningkatkan kecakapan hidup siswa. Manfaat yang diharapkan adalah tersedianya perangkat pembelajaran fisika yang dapat dijadikan acuan oleh guru dalam menyusun perangkat pembelajaran dengan metode real experiments dan virtual experiments. Perangkat pembelajaran yang dikembangkan terdiri atas enam komponen yaitu: Silabus, Rencana Pelaksanaan Pembelajaran, Buku Materi Pokok untuk Suhu dan Kalor, Lembar Kerja Siswa berbasis pendekatan saintifik, Media Pembelajaran (media tiga dimensi dan simulasi komputer), dan Tes Hasil Belajar yang diintegrasikan dengan kecakapan hidup. Model pengembangan perangkat yang digunakan adalah model 4D (Define, Design, Develop, Disseminate). Pada tahap Design telah dilakukan perancangan prototype perangkat pembelajaran sehingga penelitian ini telah menghasilkan draf produk prototype perangkat pembelajaran fisika dengan metode real experiments dan virtual experiments. Tahap Design telah selesai dilakukan sehingga penelitian pengembangan perangkat pembelajaran dapat dilanjutkan ke tahap berikutnya yaitu tahap Develop dan Disseminate.
\end{abstract}

Kata kunci: desain pembelajaran; real; virtual; experiments.

\begin{abstract}
This study aims to develop physics learning devices with methods of real experiments and virtual experiments as an effort to improve students' life skills. The expected benefit is the availability of physics learning devices that can be used as a reference by teachers in preparing learning tools with methods of real experiments and virtual experiments. The learning tool developed consists of six components: Syllabus, Learning Implementation Plan, Basic Material Book for Temperature and Heat, Student Worksheet based on a scientific approach, Learning Media (three dimensional media and computer simulation), and Learning Results Test integrated with Life Skill. The device development model used is the 4D model (Define, Design, Develop, Disseminate). In the design stage has been done designing prototype learning device so that this research has resulted draft product prototype device of physics learning with method of real experiments and virtual experiments. Stage Design has been completed so that the study of learning device development can be continued to the next stage of development and Disseminate stage.
\end{abstract}

Keywords: learning design; real; virtual; experiments.

\section{PENDAHULUAN}

Berdasarkan Laporan Hasil Ujian Nasional SMA/MA Tahun Pelajaran 2014/2015, nilai ujian untuk mata pelajaran Fisika di tingkat nasional berada pada kategori $C$ dengan nilai rata-rata sebesar 67,43 , di tingkat propinsi NTB juga berada pada kategori $C$ dengan nilai ratarata sebesar 58,95, dan di tingkat Kabupaten Lombok Barat pun nilai ujian mata pelajaran fisika berada pada kategori $C$ dengan nilai ratarata sebesar 63,03 (Puspendik, 2015). Rendahnya nilai ujian tersebut dipengaruhi oleh tingkat penguasaan materi fisika oleh siswa di
SMA/MA. Persentase penguasaan materi soal Fisika di Kabupaten Lombok Barat dapat dilihat pada Tabel 1.

Tabel 1. Persentase Penguasaan Materi

\begin{tabular}{|c|c|c|c|}
\hline No & $\begin{array}{l}\text { Kemampuan } \\
\text { Yang Diuji }\end{array}$ & Kabupaten & Nasional \\
\hline 1 & $\begin{array}{l}\text { Pengukuran } \\
\text { dan } \\
\text { Mekanika }\end{array}$ & 67,01 & 69,92 \\
\hline 2 & $\begin{array}{l}\text { Kalor dan } \\
\text { Termodinami } \\
\text { ka }\end{array}$ & 59,74 & 64,14 \\
\hline
\end{tabular}


Tabel 1. Persentase Penguasaan Materi

No Kemampuan Kabupaten Nasional
Yang Diuji

\begin{tabular}{llll}
3 & $\begin{array}{l}\text { Gelombang } \\
\text { dan Optik }\end{array}$ & 64,42 & 69,41 \\
4 & $\begin{array}{l}\text { Listrik dan } \\
\text { Magnet }\end{array}$ & 65,18 & 67,55 \\
5 & $\begin{array}{l}\text { Fisika } \\
\text { Modern }\end{array}$ & 51,45 & 60,98 \\
\hline
\end{tabular}

Tingkat penguasaan materi pelajaran merupakan salah satu indikator tingkat kecakapan akademik yang dimiliki siswa. Rendahnya tingkat kecakapan akademik siswa tersebut menunjukkan masih rendahnya tingkat kecakapan hidup siswa, khususnya di Kabupaten Lombok Barat. Berdasarkan Tabel 1, persentase penguasaan materi fisika siswa yang paling rendah di Kabupaten Lombok Barat adalah Fisika Modern sebesar 51,45, sedangkan Kalor dan Termodinamika sebesar 59,74 . Kedua materi fisika tersebut memerlukan perhatian khusus dari guru maupun pemerhati pendidikan lainnya agar siswa dapat meningkatkan penguasaan materi pada ujian nasional berikutnya. Salah satu upaya yang dapat dilakukan dari pihak Perguruan Tinggi (Dosen/Peneliti) adalah dengan melakukan penelitian pengembangan perangkat pembelajaran inovatif. Pengembangan perangkat pembelajaran yang dimaksud dapat berupa inovasi dalam metode pembelajaran maupun media pembelajaran. Dengan demikian, hasil penelitian dapat dimanfaatkan oleh guru sebagai tambahan referensi dalam menyusun perangkat pembelajaran sesuai karakteristik siswa, materi pembelajaran, dan ketersediaan sarana dan prasarana di sekolah.

Metode pembelajaran yang dimaksud diantaranya adalah metode real experiments dan virtual experiments, sedangkan media pembelajaran yang dapat dikembangkan adalah media tiga dimensi dan simulasi komputer. Penerapan Metode real experiments dan virtual experiments dalam pembelajaran diharapkan mampu meningkatkan penguasaan materi fisika seperti Kalor dan Termodinamika sebagaimana ditunjukkan pada Tabel 2 berikut.

Tabel 2. Indikator Penguasaan Materi

\begin{tabular}{llll}
\hline $\mathrm{N}$ & Kemampuan Yang & Kab & Nas \\
\hline $\mathrm{O}$ & Diuji & & \\
\hline 1 & Menentukan pengaruh & 66,6 & 75,1 \\
& $\begin{array}{l}\text { kalor terhadap suatu } \\
\text { zat, perpindahan } \\
\text { kalor/asas Black dalam }\end{array}$ & 2 \\
pemecahan masalah. & \\
& &
\end{tabular}

$\begin{array}{lll}2 \text { Menjelaskan } & 30,4 & 61,4 \\ \text { persamaan umum gas } & 9 & 3 \\ \text { ideal pada berbagai } & & \\ \text { proses termodinamika } & & \\ \text { dan penerapannya. } \\ 3 & \begin{array}{l}\text { Menentukan besaran } \\ \text { fisis yang berkaitan } 9\end{array} & 54,4 \\ \text { dengan proses } \\ \text { termodinamika pada } \\ \text { mesin kalor. }\end{array}$

Media tiga dimensi dan simulasi komputer yang dikembangkan pada materi Suhu dan Kalor dalam penelitian ini diharapkan dapat meningkatkan kemampuan siswa dalam menentukan pengaruh kalor terhadap suatu zat, dan perpindahan kalor/asas Black dalam pemecahan masalah. Dengan demikian, persentase penguasaan Materi Soal Fisika pada UN SMA/MA pada tahun-tahun berikutnya dapat meningkat, khususnya di Kabupaten Lombok Barat.

Berdasarkan wawancara dengan Ketua Musyawarah Guru Mata Pelajaran (MGMP) Fisika Lombok Barat, banyak faktor yang menyebabkan rendahnya tingkat penguasaan materi sebagai salah satu bagian dari kecakapan hidup siswa. Faktor yang dimaksud diantaranya adalah rendahnya minat siswa dalam belajar, perencanaan dan pelaksanaan pembelajaran oleh guru yang belum optimal, masih rendahnya dukungan/perhatian orang tua/masyarakat terhadap pendidikan anak, sarana dan prasarana di sekolah yang belum lengkap.

Menurut Hikmawati, Rokhmat, J., Sutrio (2015), rendahnya kecakapan hidup siswa dapat disebabkan oleh perencanaan pembelajaran yang belum optimal. Hal yang serupa juga diungkapkan oleh Ketua Kelompok Kerja Madrasah (KKM) 2 Lombok Barat, guru masih belum optimal dalam menyusun perangkat pembelajaran sebagai bagaian dari perencanaan pembelajaran di kelas. Berdasarkan wawancara dengan sebagian guru-guru yang tergabung dalam MGMP Fisika Lombok Barat maupun KKM 2 Lombok Barat membenarkan pendapat tersebut. Beberapa kendala yang dihadapi guru dalam perencanan pembelajaran diantaranya adalah masih kurangnya pengetahuan tentang metodemetode pembelajaran inovatif dan pembuatan media pembelajaran.

Penelitian ini bertujuan untuk mengembangkan perangkat pembelajaran fisika dengan metode real experiments dan virtual experiments sebagai upaya meningkatkan kecakapan hidup siswa. Dalam Anwar (2006), Depdiknas membagi kecakapan hidup menjadi empat macam yakni: (1) 
Kecakapan personal; (2) Kecakapan sosial; (3) Kecakapan akademik; (4) Kecakapan Vokasional.

\section{METODE PENELITIAN}

Rancangan penelitian dalam pengembangan perangkat pembelajaran ini menggunakan model pengembangan perangkat pembelajaran four-D (Define, Design, Develop, Disseminate) seperti yang disarankan oleh Thiagarajan, Semmel, dan Semmel (1974). Model ini diadaptasi menjadi Model 4P (Pendefinisian, Perancangan, Pengembangan, dan Penyebaran) oleh Ibrahim (2003).

Tujuan tahap Define adalah menetapkan dan mendefinisikan syarat-syarat yang dibutuhkan dalam pembelajaran. Langkah-langkah yang dilakukan pada tahap Define adalah analisis kebutuhan, analisis siswa, analisis tugas, analisis konsep, dan perumusan tujuan pembelajaran. Tujuan tahap Design adalah merancang prototype perangkat pembelajaran. Langkah-langkah yang dilakukan pada tahap Design adalah penyusunan tes, pemilihan media, dan pemilihan format. Tujuan tahap Develop adalah menghasilkan perangkat pembelajaran yang telah direvisi berdasarkan masukan dari validator. Langkah-langkah yang dilakukan pada tahap Develop adalah validasi perangkat oleh pakar, simulasi Rencana Pelaksanaan Pembelajaran, dan ujicoba terbatas. Tahap Disseminate merupakan tahap penggunaan perangkat yang telah dikembangkan pada skala yang lebih luas misalnya di kelas lain, di sekolah lain, oleh guru yang lain. Tujuan lain dari tahap Disseminate adalah untuk menguji efektivitas penggunaan perangkat di dalam kegiatan belajar mengajar.

Pada penelitian tahun pertama (2017), telah dilakukan tahap Define (Pendefinisian) dan tahap Design (Perancangan), sedangkan tahap Develop dan Disseminate akan dilakukan pada penelitian tahun berikutnya. Perangkat pembelajaran yang dikembangkan terdiri atas enam komponen yaitu: Silabus, Rencana Pelaksanaan Pembelajaran (RPP), Buku Materi Pokok (BMP), Lembar Kerja Siswa (LKS), Media Pembelajaran, dan Tes Hasil Belajar (THB).

Pada tahap Design telah dilakukan perancangan prototype perangkat pembelajaran sehingga menghasilkan draf produk prototype perangkat pembelajaran fisika. Langkah-langkah yang sudah dilakukan dalam tahap perancangan ini berdasarkan Trianto (2008) adalah penyusunan tes hasil belajar berdasarkan hasil rumusan tujuan pembelajaran, pemilihan media pembelajaran yang sesuai dengan tujuan untuk materi pelajaran, dan pemilihan format perangkat pembelajaran dengan mengkaji format-format yang sudah ada sesuai dengan kurikulum yang berlaku, yakni Kurikulum 2013.

\section{HASIL DAN PEMBAHASAN}

Tahap Define dan Design pada penelitian tahun pertama (2017) ini dilakukan di dua sekolah yang berada di Kabupaten Lombok Barat dan di Program Studi Pendidikan Fisika FKIP Universitas Mataram. Dua sekolah yang dimaksud adalah SMAN 1 Kediri dan SMAN 1 Gerung. Kedua sekolah tersebut telah berkontribusi dalam menyediakan perangkat pembelajaran untuk materi Suhu, Kalor, dan Perpindahan Kalor yang akan dikembangkan oleh Tim Peneliti. Model pembelajaran yang digunakan dalam rancangan pembelajaran penelitian ini adalah model inkuiri, metode yang digunakan adalah metode eksperimen (real dan virtual experiments), dan media pembelajaran yang digunakan adalah media tiga dimensi dan simulasi komputer. Pengembangan media pembelajaran dilakukan di Laboratorium Fisika FKIP Universitas Mataram.

Tes hasil belajar yang diintegrasikan dengan kecakapan hidup dalam penelitian ini meliputi tes pengetahuan, sikap, dan keterampilan. Adapun hasil perumusan tujuan pembelajaran untuk materi pokok "Suhu dan Kalor" pada aspek pengetahuan dalam penelitian ini adalah sebagai berikut.

1. Menjelaskan suhu dan alat ukur suhu.

2. Menjelaskan skala suhu.

3. Menjelaskan pengaruh suhu pada pemuaian zat padat, zat cair, dan zat gas.

4. Menggunakan persamaan pemuaian untuk menyelesaikan soal.

5. Menjelaskan pengaruh kalor terhadap suatu zat.

6. Menjelaskan asas Black dan menggunakan persamaannya dalam menyelesaikan persoalan.

7. Menjelaskan perpindahan kalor dan peristiwa yang berkaitan.

8. Menggunakan persamaan pada perpindahan kalor untuk menyelesaikan permasalahan.

Instrumen observasi penilaian sikap kerja individu menggunakan lembar pengamatan sikap "Tanggung Jawab, Gotong Royong, Disiplin" dalam mempelajari fisika.

Tes untuk aspek keterampilan (psikomotor) siswa yang berhasil disusun dalam penelitian ini adalah sebagai berikut.

1. Mengukur suhu dengan menggunakan thermometer. 
2. Melakukan kegiatan untuk membuktikan pemuaian zat.

3. Melakukan kegiatan percobaan tentang pengaruh kalor terhadap perubahan wujud zat.

4. Melakukan percobaan untuk menentukan Asas Black.

5. Melakukan percobaan perpindahan kalor secara konduksi, konveksi, dan radiasi.

6. Melakukan percobaan untuk menentukan persamaan kalor.

Kemampuan yang dinilai dalam lembar observasi penilaian psikomotor dalam penelitian ini adalah: Kemampuan merangkai alat; Kemampuan membaca alat ukur; Kemampuan mencatat data pengamatan; Kemampuan mempresentasikan hasil percobaan.

Media pembelajaran yang dirancang dalam penelitian ini terdiri atas media tiga dimensi dan simulasi komputer. Penerapan media tiga dimensi dan simulasi komputer dalam pembelajaran fisika di Kelas dilengkapi dengan LKS berbasis pendekatan saintifik. Dalam setiap LKS terdapat kegiatan ilmiah yaitu: Mengamati, Menanya, Mencoba, Mengasosiasi, Menyimpulkan. Media tiga dimensi yang berhasil dibuat draf prototipnya adalah:

1. Menera Termometer. Tujuan percobaannya adalah: Membedakan suhu benda; dan Menentukan konversi skala thermometer. Alat dan bahan percobaan terdiri atas wadah, air panas, air dingin/es, Termometer.

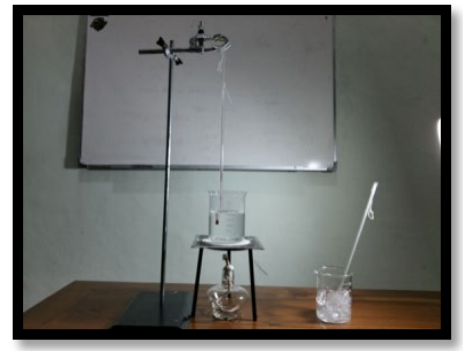

Gambar 1. Menera Termometer

2. Pemuaian Panjang dan Perubahan Wujud Zat. Tujuan percobaannya adalah: Menyelidiki pemuaian panjang; dan Mengamati perubahan wujud zat pada parafin/lilin. Alat dan bahan yang digunakan adalah: alat Musschenbroek, pembakar spiritus, tiga batang logam yang berbeda jenis, beker glass, tripod, lilin, korek api.

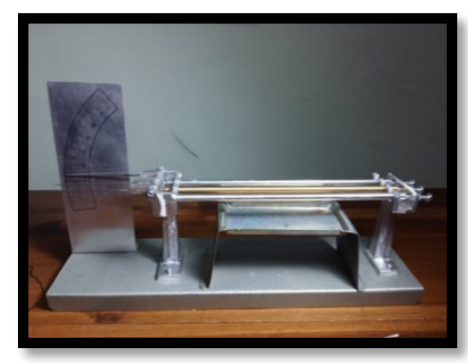

Gambar 3. Pemuaian Panjang

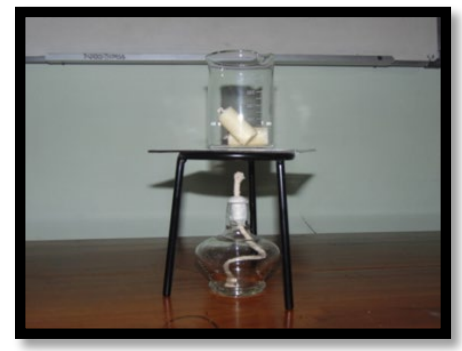

Gambar 4. Perubahan Wujud Zat

3. Pengaruh Kalor Terhadap Wujud Zat. Tujuan percobaannya adalah menyelidiki pengaruh kalor terhadap perubahan wujud benda. Alat dan bahan yang digunakan adalah: beker gelas, lampu, thermometer, statif, stopwatch.

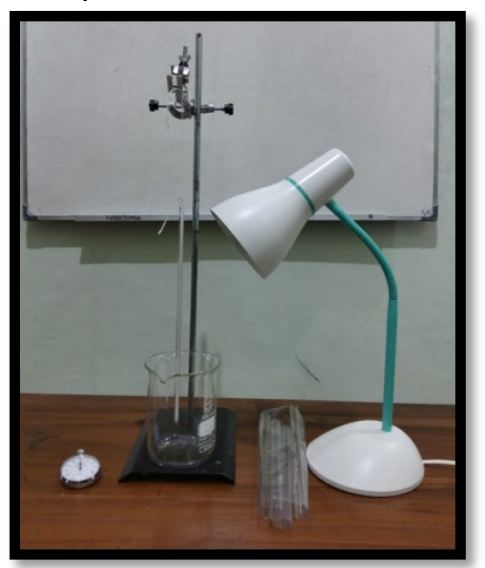

Gambar 5. Pengaruh Kalor terhadap Wujud Zat

4. Azas Black. Tujuan percobaannya adalah: Membedakan mana benda yang menerima kalor dan benda yang melepas kalor; Merumuskan asas Black untuk memecahkan masalah; Menganalisis faktor-faktor apa saja yang mempengaruhi kalor. Alat dan bahan yang digunakan adalah: Kalorimeter, gelas kimia, Thermometer, air, logam berbentuk berbentuk kubus, pemanas spiritus. 


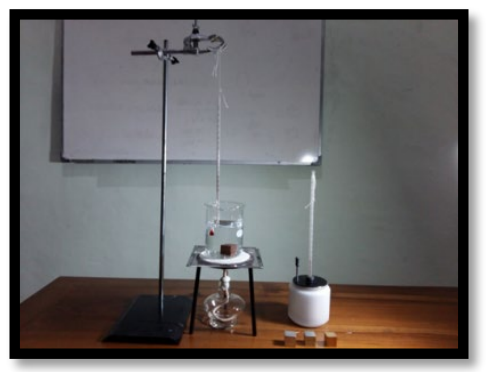

Gambar 6. Azas Black

5. Perpindahan Kalor. Tujuan percobaannya adalah: Menyelidiki hal-hal yang mempengaruhi perpindahan kalor secara konduksi pada logam. Alat dan bahan yang digunakan adalah: batang seng, besi, kaca, dan tembaga dengan variasi panjang, kaki tiga, korek api, lilin atau plastisin, pembakar spiritus.

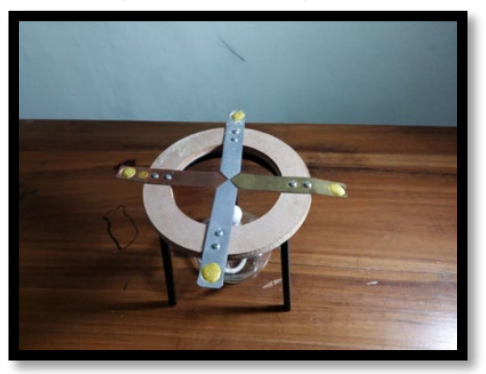

Gambar 7. Perpindahan Kalor

6. Persamaan Kalor. Tujuan percobaannya adalah: Merancang eksperimen untuk menentukan persamaan kalor. Alat dan bahan yang digunakan adalah: gelas kimia, termometer, pembakar spiritus, statif, air.

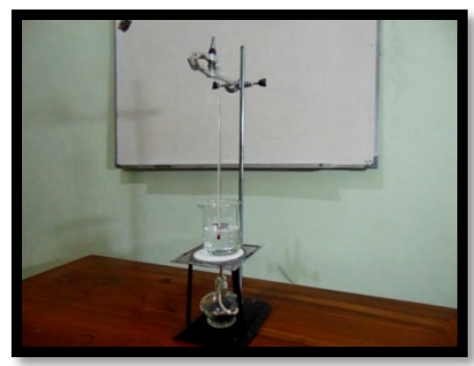

Gambar 8. Persamaan Kalor

Simulasi komputer dalam penelitian ini menggunakan program simulasi dari PhET. Dalam http://phet.colorado.edu/in/about dituliskan bahwa Physics Education Technology (PhET) merupakan simulasi interaktif fenomena-fenomena fisis, berbasis riset yang diberikan secara gratis (Perkins, et.al., 2006). Penelitian ini mengembangkan LKS berbasis pendekatan saintifik sebagai penunjang dalam penggunaan simulasi komputer dimaksud. Tujuan percobaan yang pertama adalah untuk mengetahui pengaruh kalor terhadap suhu zat, dan yang kedua adalah untuk mengetahui pengaruh kalor terhadap wujud zat. Alat dan bahan yang digunakan adalah: Laptop/Komputer, program simulasi PhET, kertas HVS.

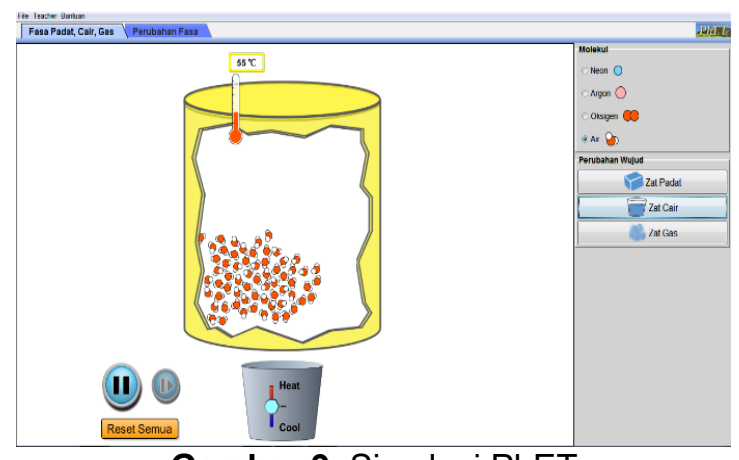

Gambar 9. Simulasi PhET

Penggunaan simulasi komputer tidak hanya berdampak positif bagi siswa, tetapi juga dapat meningkatkan kreativitas guru dalam menyusun perangkat pembelajaran, khususnya media pembelajaran untuk materi "Suhu dan Kalor". Penelitian Gunawan, dkk. (2017) mengembangkan laboratorium virtual sebagai alternatif terbatasnya peralatan eksperimen fisika dan membantu visualisasi pada berbagai konsep abstrak dalam fisika. Hasil penelitiannya menunjukkan adanya perbedaan peningkatan kreativitas calon guru fisika setelah pembelajaran pada kedua kelas. Secara umum, peningkatan kreativitas pada kelas eksperimen lebih tinggi dibandingkan kelas kontrol. Peningkatan kreativitas verbal maupun figural pada kedua kelas juga berbeda secara signifikan. Pada kedua kelas, peningkatan kreativitas verbal lebih tinggi dibandingkan kreativitas figural. Hal ini menunjukkan bahwa model laboratorium virtual yang dikembangkan terbukti dapat meningkatkan kreativitas calon guru fisika.

Hasil penelitian Gunawan, dkk. (2016) menunjukkan bahwa rata-rata penguasaan konsep siswa yang belajar menggunaan multimedia interaktif lebih tinggi dibandingkan siswa yang belajar tanpa multimedia. Penguasaan konsep kalor siswa juga dipengaruhi oleh gaya belajar, dimana siswa dengan gaya belajar visual memiliki penguasaan konsep yang lebih tinggi dibandingkan siswa dengan gaya belajar lainnya.

Hasil penelitian Tüysüz (2010) menunjukkan bahwa aplikasi laboratorium virtual memberikan efek positif terhadap prestasi dan sikap siswa bila dibandingkan dengan metode pengajaran tradisional. Kegiatan pembelajaran di laboratorium dapat 
meningkatkan minat siswa terhadap materi pelajaran. Kurangnya fasilitas laboratorium di sekolah dapat diatasi dengan pemanfaatan teknologi seperti penggunaan laboratorium virtual.

Penelitian Hatika (2016) menunjukkan bahwa animasi komputer dapat meningkatkan hasil belajar siswa. Dalam usaha mendapatkan hasil belajar siswa yang baik maka tenaga pendidikan harus mempunyai strategi dalam melakukan pembelajaran. Dalam hal menunjang penggunaan suatu model, maka diperlukannya penggunaan media pembelajaran tertentu, salah satu media yang dapat digunakan yaitu media animasi komputer. Hasil analisis daya serap dalam kategori baik, ketuntasan belajar secara klasikal sudah tuntas dan efektivitas pembelajaran adalah efektif.

Model pembelajaran yang digunakan dalam penyusunan RPP adalah model pembelajaran berbasis inkuri. Hasil penelitian Abdi (2014) menunjukkan bahwa siswa yang diinstruksikan melalui pembelajaran berbasis inquiry mendapat nilai lebih tinggi daripada yang diinstruksikan melalui metode tradisional. Jufri (2010) menuliskan sintaks umum pelaksanaan pembelajaran berbasis inkuiri terdiri atas 6 tahapan yakni: Tahap 1: identifikasi dan perumusan masalah; Tahap 2: perumusan hipotesis; Tahap 3: pengumpulan data; Tahap 4: interpretasi data; Tahap 5: pengembangan kesimpulan; Tahap 6: pengulangan. Adapun metode pembelajaran yang digunakan dalam RPP adalah metode real experiments dan virtual experiments. Pada metode real experiments siswa melakukan kegiatan penyelidikan dengan bantuan media tiga dimensi, sedangkan pada metode virtual experiments siswa melakukan kegiatan penyelidikan dengan bantuan simulasi komputer. Penelitian Ajredini, et.al. (2013) menemukan bahwa tidak terdapat perbedaan yang signifikan antara pengetahuan yang diperoleh melalui real experiments dengan melalui simulasi komputer.

Metode pembelajaran merupakan cara yang digunakan untuk mengimplementasikan rencana yang sudah disusun dalam kegiatan nyata agar tujuan yang telah disusun tercapai secara optimal (Sanjaya, 2008). Menurut Suprihatiningrum (2013), materi pembelajaran merupakan salah satu pertimbangan guru dalam menentukan metode pembelajaran, karena metode adalah cara untuk mengantarkan materi pelajaran agar tujuan tercapai.

Macam-macam metode pembelajaran yaitu: ceramah, diskusi, Tanya jawab, demonstrasi, eksperimen, resitasi, karyawisata, dan simulasi (Sanjaya, 2008 dan
Suprihatiningrum, 2013). Dalam penelitian ini akan digunakan metode eksperimen (real experiments) dan metode simulasi (virtual experiments) dalam pembelajaran fisika. Kedua metode ini merupakan metode pembelajaran berbasis aktivitas siswa. Bonwell \& Eison (1991) dalam Prince (2004) mendefinisikan belajar aktif sebagai metode pembelajaran yang melibatkan para siswa dalam proses pembelajaran. Singkatnya, pembelajaran aktif menuntut siswa untuk melakukan kegiatan belajar bermakna dan berpikir tentang apa yang mereka lakukan.

Menurut Hart, et.al. (2000), pembelajaran berbasis eksperimen dapat memberikan pengalaman bermakna bagi siswa. kegiatan belajar melalui percobaan tersebut berpengaruh baik terhadap aspek kognitif dan afektif siswa. Menurut Suprihatiningrum (2013), metode eksperimen dilakukan dengan cara mempraktekkan buku resep yang dapat berupa buku petunjuk praktikum atau petunjuk dalam mengoperasikan alat. Siswa dituntut untuk melakukan percobaan atau mengamati suatu proses dan hasilnya. Metode ini bertujuan untuk membekali siswa dengan metode ilmiah. Menurut Sanjaya (2008), sebagai metode mengajar, simulasi dapat diartikan cara penyajian pengalaman belajar dengan menggunakan situasi tiruan untuk memahami tentang konsep, prinsip, atau keterampilan tertentu. Rusman (2012) menyatakan bahwa dalam metode simulasi, materi pelajaran dikemas dalam bentuk simulasi-simulasi pembelajaran berupa animasi yang menjelaskan konten secara menarik, hidup, dan memadukan unsur teks, gambar, audio, gerak, dan paduan warna yang serasi dan harmonis. Sridadi dalam Rusman (2012) berpendapat bahwa simulasi adalah program (software) komputer yang berfungsi untuk menirukan perilaku sistem nyata (realitas) tertentu.

Draf produk prototype perangkat pembelajaran fisika dengan metode real experiments dan virtual experiments sebagai hasil dari tahap Design (perancangan) dalam penelitian tahun 2017 ini akan dilanjutkan dengan tahap Develop dan Disseminate pada penelitian lanjutan tahun berikutnya. Penerapan draf produk prototip perangkat pembelajaran fisika dalam ujicoba terbatas yang akan dilakukan pada tahap Develop maupun penelitian eksperimen pada tahap Disseminate diharapkan dapat meningkatkan kecakapan hidup siswa di tingkat SMA.

Menurut Anwar (2006), kecakapan hidup (life skills) mengacu pada berbagai ragam kemampuan yang diperlukan seseorang untuk menempuh kehidupan dengan sukses, bahagia dan secara bermartabat di masyarakat. 
Kecakapan hidup merupakan kemampuan komunikasi secara efektif, kemampuan mengembangkan kerjasama, melaksanakan peranan sebagai warga Negara yang bertanggungjawab, memiliki kesiapan serta kecakapan untuk bekerja, dan memiliki karakter dan etika untuk terjun ke dunia kerja.

Program pendidikan berorientasi kecakapan hidup melalui pendekatan pendidikan berbasis luas (Broad Based Education) sangat memungkinkan untuk dilaksanakan pada setiap jenis dan jenjang pendidikan. Selain tidak mengubah sistem kurikulum yang ada, program ini tidak menambah beban mata pelajaran baru, melainkan hanya mengubah orientasi program pembelajaran. Dengan kata lain, yang perlu diperhatikan adalah reorientasi pendidikan dari subject matter oriented menjadi life skills oriented (Tim BBE Depdiknas, 2012).

Menurut Mugambi \& Muthui (2013), kurikulum kecakapan hidup memainkan peran utama dalam memungkinkan siswa untuk menggunakan pengetahuan, sikap dan nilainilai ke dalam kemampuan pada apa yang harus dilakukan dan bagaimana melakukannya. Penelitiannya menemukan beberapa faktor yang mempengaruhi pelaksanaan kurikulum Kecakapan Hidup, yaitu: pendekatan mengajar, kurangnya konseptualisasi kecakapan hidup, sumber daya manusia yang terbatas, kurangnya pengawasan, persiapan guru masih kurang, kurangnya pilihan strategi belajar mengajar, terbatasnya penggunaan sumber daya pembelajaran, metode penilaian yang buruk, dan sikap negatif siswa terhadap kecakapan hidup. Penelitiannya menemukan bahwa pelaksanaan Pendidikan Kecakapan Hidup tergantung terutama pada kompetensi guru yang di sisi lain dipengaruhi juga oleh faktor-faktor ekstrinsik.

\section{SIMPULAN}

Kesimpulan dari penelitian ini adalah telah tersedia Draf produk prototype perangkat pembelajaran fisika dengan metode real experiments dan virtual experiments dari hasil tahap Design. Oleh karena pengembangan perangkat pembelajaran tahap kedua dari empat tahap, yaitu tahap Design, telah selesai dilakukan maka penelitian dapat dilanjutkan ke tahap berikutnya yaitu tahap Develop dan Disseminate.

\section{DAFTAR RUJUKAN}

Abdi , A. (2014). The Effect of Inquiry-based Learning Method on Students' Academic Achievement in Science Course. Universal Journal of Educational Research, 2(1): 37-41.
Ajredini, F., Izairi, N., Zajkov, O. (2013). Real Experiments versus Phet Simulations for Better High-School Students' Understanding of Electrostatic Charging. European Journal of Physics Education, 5(1), 59-70.

Anwar. (2006). Pendidikan Kecakapan Hidup (Life Skills Education): Konsep dan Aplikasi. Bandung: Alfabeta.

Arikunto, S. (2006). Prosedur Penelitian: Suatu Pendekatan Praktik. Jakarta: Rineka Cipta.

Gunawan, A. Harjono, H. Sahidu, L. Herayanti. (2017). Virtual Laboratory Of Electricity Concept To Improve Prospective Physics Teachers' Creativity. Jurnal Pendidikan Fisika Indonesia. 13(2). 102-111.

Hart, C., Mulhall, P., Berry, A., Loughran, J., Gunstone, R. (2000). What is the Purpose of this Experiment? Or Can Students Learn Something from Doing Experiments?. Journal Of Research In Science Teaching. 37(7). 655-675.

Hatika, R. G. (2016). Peningkatan Hasil Belajar Fisika Dengan Menerapkan Model Pembelajaran Advance Organizer Berbantu Animasi Komputer. Jurnal Pendidikan Fisika Indonesia. 12(2). 113-117.

Hikmawati, Rokhmat, J., Sutrio. (2015). Penyuluhan Pembuatan Media Tiga Dimensi Dan Penerapannya Melalui Model Siklus Belajar 5E Pada GuruGuru Di MGMP Fisika Se-Lombok Barat. Laporan Pengabdian. Mataram: Universitas Mataram.

http://phet.colorado.edu/in/about

Ibrahim, M. (2003). Pengembangan Perangkat Pembelajaran. Jakarta: Dirjen Dikdasmen Depdiknas.

Ibrahim, M. (2005). Asesmen Berkelanjutan: Konsep Dasar, Tahapan Pengembangan dan Contoh. Surabaya: Unesa University Press.

Jufri, A. W. (2010). Belajar dan Pembelajaran Sains. Lombok Barat: Arga Puji Press.

Kementerian Pendidikan dan Kebudayaan. (2016). Silabus Mata Pelajaran Sekolah Menengah Atas/ Madrasah Aliyah (SMA/MA) Mata Pelajaran Fisika. Jakarta: Kemendikbud.

Mugambi, M. M. \& Muthui, R. K. (2013). Influence Of Structural Context On Implementation Of Secondary School Life Skills Curriculum In Kajiado County, Kenya. International Journal of Education and Research. 1(3).

Perkins, K., Adams, W., Dubson, M., Finkelstein, N., Reid, S., and Wieman, 
C. (2006). PhET: Interactive Simulations for Teaching and Learning Physics. THE PHYSICS TEACHER, 44. 4-59.

Prince, M. (2004). Does Active Learning Work? A Review of the Research. Journal of Engineering Education, 93(3), 223-231.

Puspendik. (2015). Laporan Hasil Ujian Nasional,http://118.98.234.50/lhun/day a serap.aspx

Rusman. (2012). Belajar dan Pembelajaran Berbasis Komputer. Bandung: Alfabeta.

Sahidu, C. (2013). Pengembangan Program Pembelajaran Fisika (P3F). Mataram: FKIP Universitas Mataram.

Sanjaya, W. (2008). Strategi Pembelajaran Berorientasi Standar Proses Pendidikan. Jakarta: Kencana Penada Media.

Suprihatiningrum, J. (2013). Strategi Pembelajaran: Teori dan Aplikasi. Jogjakarta: Ar-Ruzz Media.

Sivasailam Thiagarajan, Dorothy S. Semmel, Melvyn I. Semmel..(1974). Instructional Development for Training Teachers of Exceptional Children: A Sourcebook. Indiana Univ., Bloomington. Center for Innovation in Teaching the Handicapped.

Tim BBE Depdiknas. (2012). Pola Pelaksanaan Pendidikan Kecakapan Hidup. Surabaya: SIC.

Trianto. (2008). Mendesain Pembelajaran Kontekstual (Contextual Teaching and Learning) di Kelas. Jakarta: Cerdas Pustaka.

Tüysüz, C. (2010). The Effect of the Virtual Laboratory on Students' Achievement and Attitude in Chemistry. International Online Journal of Educational Sciences, 2010, 2(1), 37-53. 